\title{
COMUNICAÇÃO DO GOVERNO FEDERAL E IDENTIDADE BRASILEIRA: ANÁLISE DAS LOGOMARCAS DOS GOVERNOS LULA E DILMA
}

\author{
Federal Government communication and Brazilian identity: \\ analysis of Lula and Dilma government's logos
}

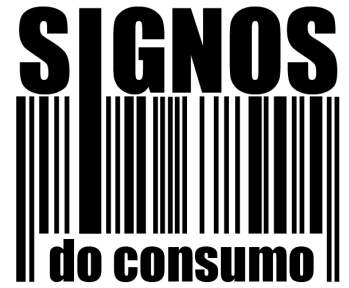

artigo

La comunicación del gobierno federal y la identidad brasileña: análisis de los logotipos de los gobiernos Lula y Dilma

\author{
Alana Jorge \\ Universidade de São Paulo, São Paulo, Brasil. \\ Graduanda em Comunicação Social, com habilitação em Publicidade e Propaganda pela Universidade de São Paulo. \\ E-mail: alanalubs@gmail.com
}

RESUMO Este artigo procura entender, por meio da semiótica aplicada, o universo de sentido e os traços identitários brasileiros utilizados na comunicação do Governo Federal. Ao analisar as logomarcas dos governos Lula e Dilma, observou-se grande diferença entre os signos utilizados: enquanto no Governo Lula a miscigenação do povo brasileiro ganhava destaque, no Governo Dilma, o tema da desigualdade social e a estabilidade/força do Estado passam a ser o foco (dialogando com a crise de representação política atual).

PALAVRAS-CHAVE Semiótica, Identidade, Brasil, Logomarca, Governo Federal.

\begin{abstract}
This article aims to understand, within applied semiotics perspective, the universe of meaning and the Brazilian identity characteristics used by Brazilian's Federal Government communication. With the analysis of Lula and Dilma Government's logos, it was observed a great difference between the used signs: Lula's Government highlighted the miscegenation of Brazilian people, and Dilma's Government focused on social inequality and the stability/strength of the State (messages that dialogue with the political current crisis in Brazil).
\end{abstract}

KEYWORDS Semiotics, Identity, Brazil, Logo, Federal Government.

RESUMEN En este artículo se busca entender, por medio de la semiótica aplicada, el universo de sentidos y los rasgos identitarios brasileños utilizados en la comunicación del Gobierno Federal brasileño. Mientras se analizan los logotipos de los gobiernos Lula y Dilma, se observa una gran diferencia entre los signos utilizados: aunque en el periodo Lula se destacaba el mestizaje del pueblo brasileño, en el periodo Dilma, el tema de la desigualdad social y la estabilidad/fuerza del Estado pasaron a ser el foco (dialogando con la actual crisis de representación política).

PALABRAS CLAVE Semiótica, Identidad, Brasil, Logotipo, Gobierno Federal. 


\section{INTRODUCÃO}

Atualmente, o Brasil passa por uma crise de representação política. Com a pós-modernidade e a globalização, há, naturalmente, um enfraquecimento das culturas nacionais (Hall, 2011) e um desinteresse da população pela participação política, tornando-se mais um objeto de consumo do que de discussão (Canclini, 1996). Porém, no Brasil, somado a esse movimento, há um processo de desmoralização das instituições públicas, contaminadas pelos meios de navegação social explicados por DaMatta (2004) - o "jeitinho brasileiro" e o "sabe com quem está falando?” - ambas colocando as relações sociais acima da lei.

Sorj (2000) explica que a política e o Estado são vistos como algo que traz rentabilidade (e dinheiro) e não asseguram a cidadania da população (necessidades coletivas). Há uma descrença geral na ordem política, e os brasileiros passam a desejar algum tipo de transformação institucional para limitar o "poder" dos candidatos/partidos políticos (que se sobrepõe aos direitos dos cidadãos), além da libertação da política em relação à apropriação privada, "que o parlamentar deixe de ser simplesmente um lobista de interesses particulares, tornandose também porta-voz de um projeto societário" (Ibid., p. 27). Nesse contexto de crise, portanto, é essencial que o Estado consiga se comunicar com a população (para evitar maiores transtornos na relação entre Governo e povo brasileiro), procurando corrigir aspectos que causem essa descrença. O presente estudo procura ir ao encontro dessa questão.

Para que a comunicação cause o efeito desejado sobre as pessoas, sabe-se que deve haver um entendimento compartilhado de seus signos entre emissor e receptor, já que ele "sempre funciona como mediador entre o objeto e o interpretante” (Santaella, 2008, p. 9). Somado a isso, a comunicação se torna eficaz quando o emissor atende às expectativas do receptor, vai ao encontro de seus valores e propósitos e o envolve (Sousa, 2006). Dessa forma, quanto mais próximos da vida de seu público-alvo, mais os signos de uma comunicação serão inteligíveis (irão ao encontro de experiências anteriores ou memórias) e criarão identificação com o que é passado na mensagem.

A proximidade criada com o público-alvo está relacionada com uma propriedade do signo apresentada por Bakhtin (1998). O autor nos explica que os signos refletem uma realidade, na medida em que representam algo existente em uma sociedade; ao mesmo tempo, porém, essa representação é capaz de refratá-la. Isso significa que, conforme representamos nosso mundo através de signos, somos capazes de afirmar suas características, mas também de modificá-las, criando novas percepções e compreensões.

Os signos utilizados na comunicação do Governo Federal também lidam com isso. Para se comunicar com a população, é importante que o Estado reflita os brasileiros de alguma forma (gerando identificação). Mas, ao mesmo tempo, tem o poder de refratar uma realidade, mudando a visão do país e dos próprios brasileiros. Em meio a uma crise de representação política, trazer de volta a "estabilidade" do Estado torna-se essencial.

Nesse contexto, pretende-se analisar, através da metodologia de semiótica aplicada apresentada por Santaella (2008), o universo de sentido e os possíveis traços identitários utilizados nas comunicações do Governo Federal, mais especificamente, na identidade visual do 
governo (logomarcas). Ao estudar os três âmbitos do signo (qualitativoicônico, singular-indicativo e convencional-simbólico), identificou-se os universos de sentidos utilizados em cada uma das assinaturas do Governo Federal, de 2007 até 2016 (ao todo, três identidades visuais distintas), assim como traços identitários brasileiros.

O material foi escolhido por conveniência, e tentamos analisar uma pequena série histórica. Porém, as identidades visuais de governos anteriores ao de Lula não foram encontradas em sites oficiais. Isso vai ao encontro da falta de lógica institucional do Estado brasileiro. Segundo Sorj (2000), faz parte da democracia brasileira, que ainda é jovem, não racionalizar ou construir uma lógica institucional de desenvolvimento contínuo ao longo dos anos, principalmente ao longo de diferentes governos. Isso significa que, de alguma forma, o progresso e as medidas desenvolvidas no governo anterior são "apagadas” para dar origem a um "novo país".

Visto isso, definiu-se como objeto de estudo apenas os logos encontrados em comunicações oficiais, e por meio desta análise, observou-se que as três logomarcas, de alguma forma, trabalham com traços identitários brasileiros, ainda que, entre os diferentes governos, haja mudança significativa no universo de sentido.

Entre os traços identitários utilizados, está o mito da três raças fundadoras e a característica mestiça/diversificada do povo brasileiro, que se une em sua diferença, explicada por autores como por Darcy Ribeiro (2013) e Renato Ortiz (2012). Outro aspecto importante da identidade brasileira é a característica de sociedade relacional. Segundo DaMatta (2004), a população brasileira vive em uma ambiguidade constante, sempre entre conceitos contraditórios, porém que se equilibram. Um exemplo são os conceitos de casa (lar, família, amor) e rua (impessoalidade, lei, exploração). Há também a desconstrução do mito do "país do futuro" (outro traço identitário brasileiro) - ideia de que o Brasil, por ser um país continental, com muitas riquezas naturais, se tornará uma potência mundial, um país rico. Essa expressão é o nome do livro de Stefan Zweig (2001), sendo apropriada e desenvolvida pelo Estado (principalmente pelo governo de Juscelino Kubitschek) e transmitida ao longo dos diferentes governos.

A contradição, porém, continua no seio da identidade brasileira: país “rico”, possível grande potência, com desigualdade social gritante. Segundo Furtado (2003), através do desenvolvimento econômico, em países desenvolvidos, o lucro conseguido de alguma forma é apropriado pelo Estado, e os frutos do progresso são repartidos pela população. Porém, em economias subdesenvolvidas (como o Brasil), canais de difusão não são espontaneamente formados, gerando concentração de renda.

O presente estudo iniciou-se como um trabalho de conclusão de curso (TCC) e foi feito de maneira exploratória. O objetivo não foi captar todos os traços identitários brasileiros, mas sim, a partir da bibliografia consultada, entender qual o potencial comunicativo e o universo de sentido utilizados. Desse modo, está aberto para futuras pesquisas complementares.

1. Originalmente publicado em 1942. 


\section{MATERIAIS E MÉTODOS}

Este estudo analisou o universo de sentido utilizado na comunicação do Governo Federal, por meio de sua identidade visual. Investigou-se o potencial comunicativo dessa identidade visual e como, por meio de signos e traços identitários brasileiros, o Estado procura se comunicar com seu público (brasileiros). Para isso, como objeto de estudo, foram escolhidas três logomarcas do Governo Federal, para que fosse possível observar possíveis mudanças de um governo para outro. A primeira logomarca é do segundo mandato do presidente Lula (2007-2010); a segunda, do primeiro mandato da presidenta Dilma (2011-2014); e a última, do seu segundo mandato (2014-2016).

A escolha do material foi feita por conveniência, porque, como explicado, graças à falta de lógica institucional do Estado brasileiro (Sorj, 2000), há uma grande dificuldade em encontrar quaisquer informações sobre governos antigos. Para evitar equívocos, portanto, optou-se por captar uma pequena série histórica, com logomarcas encontradas em alguma comunicação oficial do Governo Federal.

Como já mencionado, a metodologia utilizada foi a semiótica aplicada apresentada por Santaella (2008), baseada na teoria geral dos signos, de Charles S. Peirce. Segundo a autora, o signo possui natureza triádica: ele em si mesmo (propriedades internas, seu poder de significar); em sua referência àquilo que indica (se refere ou representa - objeto); e nos diversos efeitos a que está apto para produzir nos receptores (interpretante).

Dessa forma, existem certas propriedades que dão às coisas a capacidade de funcionar como signos: "sua mera qualidade, sua existência, ou seja, o simples fato de existir, e seu caráter de lei” (Ibid., p. 12). Esses três aspectos, por sua vez, dão origem a diferentes tipos de signos: quali-signos (qualidade por si só funciona como signo); sin-signos (singulares, indicam algo existente no real); e legi-signos (representam algo, são construídos e entendidos a partir de convenções sociais).

A relação de cada um desses signos com seus objetos gera ícones, índices e símbolos:

enquanto o ícone sugere através de associações por semelhança, o índice indica através de uma conexão de fato, existencial, o símbolo representa através de uma lei [...] nada no ícone é definitivo. Tudo depende de cadeias associativas que o signo icônico está apto a provocar no intérprete. (Ibid., p. 20, 38)

Já no caso dos índices, "as possibilidades interpretativas são fechadas [...] Por ser uma relação dual, na qual signo e objeto estão dinamicamente conectados, o potencial interpretativo dos índices se reduz à ligação existencial” (Ibid., p. 38). E o símbolo mostrase incompleto "na medida em que só funciona como signo porque determina um interpretante que o interpretará como símbolo, e assim indefinidamente" (loc. cit.).

No presente estudo, analisou-se três diferentes pontos de vista (resultantes das características descritas) para descobrir o universo de sentido utilizado em cada Governo separadamente (através dos âmbitos qualitativo-icônico, singular-indicativo e convencional-simbólico). Depois, foi realizada uma análise comparativa, identificando diferenças na comunicação. 


\section{RESULTADOS E ANÁLISES}

\section{Identidade visual do período Lula (2007-2010) - "Brasil: um país de todos"}

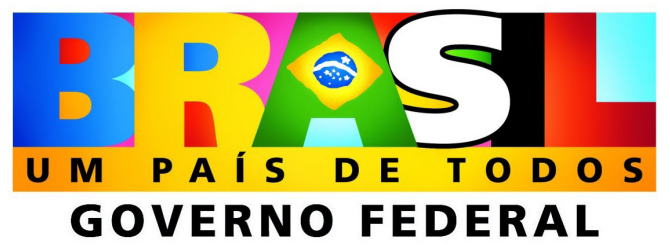

Figura 1. Logo do Governo Federal - Governo Lula. Fonte: Brasil ([2007?]).

\section{Ponto de vista qualitativo-icônico}

A logomarca antiga do Governo Federal apresenta forma retangular, com letras em caixa-alta e negrito, remetendo a algo masculino, mais duro. Esse aspecto tem relação com o fato de o Estado precisar se impor; com letras mais grossas e pesadas, mantém algo de imperativo, de peso, de importância. O slogan "Um país de todos" aparece abaixo do nome do país, com menos destaque, em preto e alinhado às letras de cima. Da mesma forma, o nome "Governo Federal” aparece mais sóbrio (na cor preta), na parte inferior, com maior destaque do que o slogan, pois o fundo é branco (as letras saltam mais aos olhos).

O nome "Brasil" é a parte mais importante da logomarca. Está centralizado e é para onde o olhar se direciona, e cada letra tem uma combinação de cores. Ao todo, são 10: vermelho, azul, azul-claro, amareloouro, amarelo-claro, preto, branco, rosa, vermelho e verde. Essa profusão traz duas ideias essenciais para entendermos o logo. A primeira é que o Brasil é um país diverso, com diferentes cores, pessoas, etnias, religiões. Aspecto fundador da identidade brasileira, estudado por nomes como Darcy Ribeiro (2013) e Renato Ortiz (2012), reforçado pela palavra “Todos” do slogan; a segunda é que, com essa quantidade de cores, a logomarca passa um sentimento de que o Brasil é um país alegre, feliz, carnavalesco, outro aspecto de muito orgulho para a identidade nacional. Assim, confirma-se a imagem de nação "mestiça e tropical, orgulhosa de si mesma. Mais alegre, porque mais sofrida. Melhor, porque incorpora em si mais humanidades. Mais generosa, porque aberta à convivência com todas as raças e todas as culturas” (Ribeiro, op. cit., p. 411). Ao mesmo tempo, portanto, que o Governo Federal se mostra imperativo, com letras grossas e anguladas, as diferentes cores quebram essa percepção, fazendo o conjunto passar uma ideia de diversidade, miscigenação e alegria.

Interessante observar que, apesar da mistura de cores, parece haver uma divisão da palavra "Brasil": as três primeiras letras ("BRA") têm prioritariamente cores da bandeira brasileira, mais leves e luminosas (chamam mais atenção) - azul, amarelo ouro e verde; as três últimas, porém, ("SIL”) têm cores mais pesadas, contrapostas: branco (com contorno em preto), preto e vermelho. Aqui também enxergamos a questão da diversidade, mas com uma informação ainda mais importante por trás. "SIL" remete à ideia das três raças fundadoras brasileiras, das quais Darcy Ribeiro (2013) fala: o "S" lembra aos portugueses (povo branco); o “I”, ao povo africano (negros); e o “L”, aos índios (representado 
pelo vermelho). Apenas por essas três cores, temos mais um traço identitário brasileiro: o "Brasil-cadinho” (Ortiz, 2012), a mistura das três raças fundadoras e a criação do mestiço, que se tornou "senso comum, ritualmente celebrado nas relações do cotidiano, ou nos grandes eventos como carnaval e futebol. O que era mestiço torna-se nacional” (Ibid., p. 41). Dessa forma, o mestiço passou a ser aceito enquanto possibilidade de uma identidade autenticamente brasileira (Freyre apud Trindade, 2012). Portanto, há uma "síntese perfeita do melhor que pode existir no negro, no branco e no índio” (DaMatta, 2004, p. 23).

Ao centro do nome, na letra "A”, há um losango e uma circunferência que nos remetem à bandeira do Brasil, com desenho simplificado, traços inconstantes, parecido ao desenho de uma criança. A sombra da palavra e essa imagem direcionam o olhar para o centro do logo.

\section{Ponto de vista singular-indicativo}

Como vimos na questão das qualidades do logo, ele sugere a diversidade no Brasil e indica o discurso prioritário do Governo Federal. O "País de todos" traz o assunto da diversidade do povo brasileiro, mas também da necessidade de inclusão e diminuição da desigualdade social.

\section{Ponto de vista convencional-simbólico}

Como mostrado, a presença de diversas cores no mesmo logo traz a imagem do povo brasileiro miscigenado e diverso. A forma como as letras da palavra "Brasil" estão posicionadas reforça essa ideia: muito próximas, complementam-se, representando justamente a união do povo brasileiro que, em sua diversidade, se torna um só. Além disso, o slogan "Um país de todos” revela a ideologia da igualdade social, de raça, gênero etc.

Finalmente, a logomarca mostra-se marcante, sendo identificada e entendida de maneira rápida. Ao mesmo tempo, possui muita informação (muitas cores), gerando alguma poluição visual.

\section{Identidade visual do período Dilma (2011-2016)}

As duas identidades visuais do Governo Dilma apresentam as mesmas características quanto aos aspectos gráficos, porém o slogan é modificado. Por isso, no presente texto, ambas foram analisadas em conjunto, salientando diferenças nos slogans.

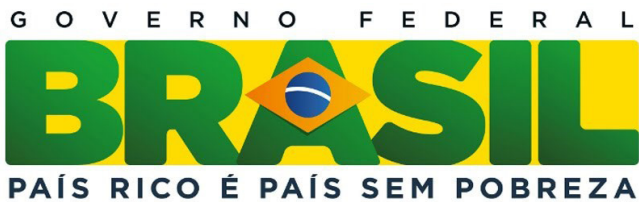

Figura 2. Logo do Governo Federal - Governo Dilma 2011-2014. Fonte: Portal Brasil (2011). 


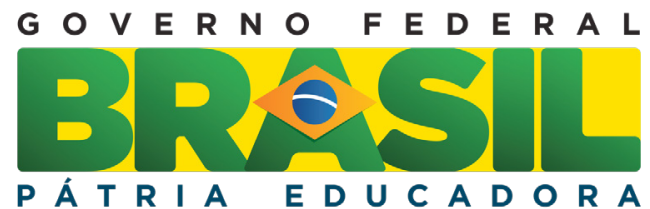

Figura 3. Logo do Governo Federal - Governo Dilma 2015-2016

Fonte: Brasil (2015).

\section{Ponto de vista qualitativo-icônico}

As logomarcas mais atuais do Governo Federal continuam com formato retangular, porém agora os cantos são mais arredondados, da mesma forma que as letras. Isso traz harmoniza aos logos, agora menos pesados. As letras continuam em caixa-alta, porém há menos cores e mais padronização: fundo amarelo com letras verdes. Aqui já observamos a mudança de discurso do governo. Antes, focado na diversidade e no carnavalesco, na alegria, as logomarcas do Governo Dilma trazem seriedade e força do Estado.

"Governo Federal” está na parte superior, com maior destaque: na primeira, está em preto e com letras mais finas do que na segunda. Portanto, no segundo mandato, "Governo Federal” (em negrito) tem um aspecto "encorpado", harmonizando-se mais com as letras arredondadas de "Brasil". Da mesma forma, os slogans ("País rico é país sem pobreza" e "Pátria educadora”) apresentam ar mais sóbrio. Ambos estão em azul-escuro, representando estabilidade, porém o segundo apresenta um tom mais claro, trazendo mais leveza, vida para a logomarca. No centro de "Brasil", ainda há a bandeira. Mas dessa vez mostra-se menos infantilizada, com traços retos e formato mais tradicional, remetendo novamente a uma maior seriedade.

\section{Ponto de vista singular-indicativo}

As logomarcas mais novas indicam uma mudança de ideologia e foco entre os governos Lula e Dilma: menos carnavalesco para mais sóbrio e estável. Qualitativamente, apresentam características distintas, e os slogans já direcionam o tema que será seguido, sugerindo que o Brasil é um país que possui pobreza, ao mesmo tempo que é visto como rico ou que é um Estado focado na educação (e, se focado na educação, também no desenvolvimento nacional).

\section{Ponto de vista convencional-simbólico}

Por meio dessas logomarcas, no Governo Dilma, o Estado deixa de ser simpático e alegre para se tornar mais sério, contemporâneo, eficiente e estável. E ambas trabalham com pautas mais definidas, que podem ser enxergadas pelos slogans.

O "País rico é país sem pobreza" tenta desconstruir o mito do "país do futuro". Assim, o Brasil deixa de ser aquele país rico, devido a suas riquezas naturais e seu potencial econômico, para se tornar o país da desigualdade social, trazendo a contradição brasileira explicada por Furtado (2003) para o centro do discurso.

O "Pátria educadora" traz outros significados, e, para entendêlos, cabe revisar alguns assuntos. DaMatta (1997) defende que há um 
conflito entre os conceitos de "pessoa" (subjetiva, importante, única) e "indivíduo" (distante, impessoal) na sociedade brasileira. Diferentemente de outras sociedades (como os EUA), a importância da pessoa no Brasil acaba se sobrepondo à do indivíduo, sujeitando a população a uma "escala de direitos e deveres vindos de cima para baixo, dos superiores para os inferiores, dos 'elementos' que entram na fila e das 'pessoas' que jamais são vistas em público como comuns” (Id., 2004, p. 40). O Brasil, portanto, é um país com relações hierárquicas fortes e sociedade "gregária, fundada na inserção em redes e, por extensão, na valorização dos contatos pessoais” (Sorj, 2000, p. 31). Estamos sempre em um sistema social dividido: o do indivíduo (leis universais, da rua, do trabalho) e o das relações pessoais.

O mundo do "indivíduo" se relaciona ao conceito de "rua" (DaMatta, op. cit.): vista como o lugar da massa, da exploração/pobreza, do Estado/ da lei, ou seja, da impessoalidade. O mundo da "pessoa", por sua vez, representa a casa, família, comida, relações interpessoais, subjetividade, personalidade. Dessa forma, temos diferentes Brasis: "os que se definem pelas instituições formais como o Estado, a constituição, o mercado, o dinheiro, quanto o país do jeitinho, da comida, das relações étnicas, da mulher, da religião" (Ibid., p. 8).

Ambas as palavras ("Pátria” e "educadora”), de alguma forma, trabalham com essa dualidade. A primeira, por si só, já é bem forte. Utilizada no hino nacional, representa o nacionalismo, o orgulho de ser brasileiro, a força, o Estado. Mas também remete à "pátria-mãe" e à cultura nacional - fazer parte da pátria é participar de uma sociedade, de uma classe, de uma nação, que a pessoa "reconhece instintivamente como seu lar" (Scruton apud Hall, 2011, p. 48). Dessa forma, já trabalha, de modo ambíguo, tanto com o conceito de "casa" quanto de "rua".

A segunda, por sua vez, pode representar uma mãe, uma guia, um cuidado (a casa, o carinho). Por outro lado, pode trazer a ideia de hierarquia (ensino de "cima para baixo") e de controle do Estado (a rua, o indivíduo, a lei). Ser "educadora” é conformar a população às leis do Estado, e, para os brasileiros, isso pode ir ao encontro da ideia de indivíduo, impessoalidade e exploração/lei, confirmando um sentimento negativo perante ao governo.

Por outro lado, "educadora” deixa clara a nova pauta do Governo Federal: educação cidadã (não só educação das crianças, mas de toda a população). E representa, portanto, a diferença de discurso e de foco das ações governamentais. Antes, a diminuição da desigualdade social era trabalhada através do consumo. Segundo Singer (2013), o lulismo baseava-se, já em 2006, na diminuição da pobreza, com manutenção da ordem do capital; o Governo Dilma focava o desenvolvimento humano e social (por meio da cidadania e da reforma).

Nas últimas duas logomarcas, portanto, o Governo Federal parece querer impulsionar a crença dos cidadãos no país: apresenta uma identidade visual mais estável, mais sóbria, ao mesmo tempo que a frase procura puxar a população. O slogan "País rico é país sem pobreza” é mais distante, trazendo a desigualdade social para o centro do discurso, e chama a população para lutar contra a pobreza. O slogan "Pátria educadora”, por sua vez, trabalha de uma forma mais emotiva, tentando recuperar o orgulho de ser brasileiro, o sentimento de pertencimento (de pátria) e de cuidado (educadora), porém também pode criar sensação de domínio, hierarquia. Ambos trabalham a favor da força do Estado e 
tentam fazer os brasileiros acreditarem novamente que o governo poderá trazer a cidadania.

\section{REFLEXÕES}

A logomarca do Governo Federal é um dos principais meios de comunicação entre cidadãos e Estado. Funciona como um selo, uma confirmação da presença do Governo Federal, e está presente em diversas comunicações.

Assim como a bandeira, é um símbolo (e um legi-signo) e, além de representar o Estado brasileiro como um todo, traz também um programa específico de Governo (suas pautas). Conforme mostrado, como signo, o logo representa mas também refrata uma realidade (Bakhtin, 1998). Por isso, é capaz de, por meio de traços identitários, contribuir para afirmar ou reconstruir a identidade nacional.

Comparando as três logomarcas, observou-se que, independentemente do período, a identidade visual do Governo Federal sempre teve as cores da bandeira brasileira: verde, amarelo, azul e branco. Além disso, o nome "Brasil" é o centro do logo e está escrito em caixa-alta, dando maior ênfase e "peso" à nação. O nome "Governo Federal” também aparece em destaque: letras pretas, em caixa-alta e fundo branco.

As semelhanças, porém, parecem terminar por aí. A logomarca utilizada durante o governo de Lula (2007-2010) trabalhava com um universo de sentido baseado no mito das três raças fundadoras e na definição de povo diverso, porém mestiço (Ribeiro, 2013; Ortiz, 2012), aspectos focados em características mais diretas da população brasileira. Dessa forma, o país é representado como um local quase místico, com a ideia do "Brasil-cadinho" (Ortiz, 2012), com muita diversidade e miscigenação, mas que, justamente nessa diversidade, encontra sua união. O logo trabalha, portanto, com o orgulho de ser um povo acolhedor. Esse aspecto é apresentado tanto de modo qualitativo (pela efusão de cores) como de modo simbólico (representação das três raças fundadoras no "SIL" e do slogan "País de todos").

Ainda pela quantidade de cores e traços mais rústicos (bandeira do Brasil desenhada de modo simplificado), a identidade visual do Governo Lula traz algo mais leve, que remete ao carnaval e às múltiplas festas e cidades brasileiras. Após a análise, ao ler o Manual de identidade visual (Brasil, [2007?]), observou-se que esse fator foi pensado para aproximar a realidade do Brasil ao Estado, ou seja, captar traços identitários brasileiros para que o povo pudesse se enxergar nisso: "não se trata mais de levar Brasília para o Brasil, de fazer o país real parecer com a imagem e a semelhança do núcleo das decisões. Ao contrário, a nova marca assume a necessidade de levar mais Brasil para Brasília” (Ibid., p. 3).

Ao contrário da anterior, porém, a partir do primeiro mandato de Dilma, a identidade visual fica mais sóbria, traz ar de eficiência e trabalha com temas mais relacionados ao Estado do que ao povo em si (economia, educação/cidadania, nacionalismo). Há menos cores e mais padronização: fundo amarelo, letras de "Brasil" em verde, slogan em azul-marinho e o restante branco e preto. A bandeira no interior da palavra tem traços retos, formatados, mais formal e séria. Dessa forma, apesar de as letras estarem mais arredondadas (e, portanto, trazerem mais harmonia e delicadeza), as logomarcas geram maior percepção de estabilidade. 
Essa seriedade também vem do slogan. No primeiro mandato de Dilma ("País rico é País sem pobreza”), ele explicita a pauta do Governo Federal (acabar com a pobreza), mas também desconstrói um traço identitário brasileiro que, de alguma forma, trazia esperança ao País - 0 mito do "país do futuro". Enquanto o "País de todos" afirma o mito da miscigenação no Brasil, no primeiro mandato, o mito é retrabalhado. O discurso de "potência econômica" dá lugar à contradição essencial brasileira: país com muitas riquezas e grande potencial, porém com grande desigualdade social (e pouco desenvolvimento industrial - eternamente subdesenvolvido). O universo de sentido, portanto, comparado à logomarca do Governo Lula, é disruptivo; torna-se racional.

Como a população já passava por um momento de descrença em relação ao futuro do país (que, teoricamente, seria a próxima potência mundial), essa desconstrução parece adequada. Já que estamos no "século XXI e as aspirações são, em certas medidas, as mesmas de outras épocas, só que agora o futuro não tem mais data para chegar e existe o peso da descrença” (Trindade, 2012, p. 116).

No segundo mandato, o slogan é trocado (pois há novas pautas para o governo), e a mensagem passada também. O "Pátria educadora" parece ser uma tentativa de "grito de guerra". A palavra "Pátria", utilizada no hino nacional, representa ao mesmo tempo o nacionalismo, a força do país, o Estado; e a mãe, o acolhimento, o lar. O termo "educadora” é responsável pela divulgação do novo foco do Governo Federal: a educação e a cidadania. Novamente, ela traz ideias ambíguas: a educadora pode representar a mãe, que guia, que ajuda; mas também a hierarquia, o controle e a adequação ao Estado. Combinado com o estilo de letras (caixaalta, anguladas, em cor escura), o slogan torna-se forte e imperativo, porém traz maior carga "emocional” do que o anterior. Ele parece uma tentativa de chamar o brasileiro, de fazê-lo orgulhoso do país novamente.

De qualquer forma, ambas as identidades visuais do Governo Dilma pareciam tentar minimizar a crise de representação política atual. Como já comentado, a descrença em relação ao Estado vem da falta de "futuro" do país, mas também do enfraquecimento do Estado e da imagem da classe política (desmoralização das instituições públicas). Portanto, com ar mais sóbrio/sério e mantendo o estilo gráfico de um governo para o outro, as identidades visuais dos governos de Dilma, diferentemente do Governo Lula, tentam passar mensagem de robustez, continuidade e confiança.

\section{CONSIDERAÇÕES FINAIS}

A partir da análise da marca do Governo Federal, foi possível identificar que o Estado de fato utiliza alguns traços identitários brasileiros para se comunicar com a população: miscigenação, ideia de desigualdade social versus potência econômica, dualidades vividas pelo povo brasileiro - conceitos de "rua" e de "casa" (DaMatta, 2004). Visto isso, por usar esses traços, as logomarcas do Governo Federal contribuem para afirmar ou reconstruir uma identidade nacional.

Esse processo, porém, apresenta contornos distintos entre os três mandatos. No Governo Lula, o povo brasileiro foi representado de maneira mais direta, através das ideias de miscigenação e carnaval/ alegria. No Governo Dilma, as ideias passadas se relacionavam mais ao Estado como um todo (não especificamente à população). Nesse caso, apesar de utilizar aspectos que ainda faziam parte da identidade do país 
(desigualdade social, mito do "país do futuro", força/hierarquia do Estado, nacionalismo), a referência (direta) ao povo brasileiro não é tão clara. A identidade visual foi bem trabalhada graficamente para representar a força e a estabilidade do Estado, mas gerou uma espécie de ruptura, com universos de sentido bem diferentes entre os governos.

A identidade visual do Governo Dilma, por outro lado, se manteve consistente (mesmo logo, mudando apenas o slogan), o que é bastante positivo, pois, com o tempo, passa a funcionar de fato como um selo, facilitando a comunicação entre emissor e receptor, além de mostrar a estabilidade do Estado.

Contribuindo ainda mais para alinhar a comunicação entre Estado e população, no Governo Dilma, a logomarca tinha relação direta com a situação pela qual o país passava:

- Ambas: são mais sérias e trazem a confiabilidade/estabilidade do Governo Federal - colaborando para diminuir a crise de representação política;

- "País rico é País sem pobreza”: desconstrói o mito do "país do futuro", justamente em um período de descrença da população diante da economia e da possibilidade de se tornar uma potência mundial;

- "Pátria educadora": tem ideias ambíguas, mas tenta trazer de volta o orgulho de ser brasileiro (em meio à crise de representação política e econômica) e apresenta novo foco do governo (educação/cidadania) em relação ao anterior (melhoria de vida pelo consumo).

Finalmente, como este estudo foi realizado de maneira qualitativa e exploratória, poderá ser trabalhado no futuro. Uma das alternativas de estudo posterior é o tema pelo lado do receptor. Já foi verificado o universo de sentido passado pelo emissor (Governo Federal); dessa forma, acredita-se ser bastante relevante, através de entrevistas ou questionários com brasileiros, verificar como a identidade visual do Governo Federal influencia a visão da população perante o Estado e se, de fato, passa as mensagens a que se propõe.

\section{REFERÊNCIAS}

BAKHTIN, M. Marxismo e filosofia da linguagem. São Paulo: Hucitec, 1998.

BRASIL. Secretaria de Comunicação e Gestão Estrangeira. Manual de identidade visual. [2007?]. Disponível em: <http://bit.ly/2n9ZNtA>. Acesso em: 10 abr. 2016.

Secretaria de Comunicação e Gestão Estrangeira do Paraná. Manual de uso da marca do Governo Federal. 2015. Disponível em: <http://bit.ly/280djzB>. Acesso em: 10 abr. 2016.

CANCLINI, N. Consumidores e cidadãos: conflitos multiculturais da globalização. 2. ed. Rio de Janeiro: UFRJ, 1996.

DAMATTA, R. Carnavais, malandros e heróis: para uma sociologia do dilema brasileiro. Rio de Janeiro: Rocco, 1997.

O que é o Brasil? Rio de Janeiro: Rocco, 2004. (Coleção Jovens Leitores).

FURTADO, C. Raízes do subdesenvolvimento. Rio de Janeiro: Civilização Brasileira, 2003.

HALL, S. A identidade cultural na pós-modernidade. 11. ed. Rio de Janeiro: DP\&A, 2011. 
ORTIZ, R. Cultura brasileira e identidade nacional. 5. ed. São Paulo: Brasiliense, 2012.

PORTAL BRASIL. Governo lança nova logomarca com slogan "País rico é país sem pobreza”. 2011. Disponível em: <http://bit.ly/2oaboea>. Acesso em: 10 abr. 2016.

RIBEIRO, D. O povo brasileiro. 12. reimpr. São Paulo: Companhia das Letras, 2013.

SANTAELLA, L. Semiótica aplicada. São Paulo: Cengage Learning, 2008.

SINGER, A. Os sentidos do lulismo: reforma gradual e pacto conservador. 1. ed. São Paulo: Companhia das Letras, 2013.

SORJ, B. A nova sociedade brasileira. 2. ed. Rio de Janeiro: Jorge Zahar, 2000.

SOUSA, J. P. Elementos de teoria e pesquisa da comunicação e dos media. 2. ed. 2006. Disponivel em: <http://bit.ly/2o2X5eB>. Acesso em: 28 out. 2014

TRINDADE, E. Propaganda, identidade e discurso: brasilidades midiáticas. Porto Alegre: Sulina, 2012.

ZWEIG, S. Brasil, país do futuro. 2001. Disponivel em: <http://bit.ly/2no9p5J>. Acesso em: 30 out. 2014. 